\title{
The genetics of natalizumab hypersensitivity
}

\author{
One learns to itch where one can scratch
}

\section{OPEN}

Olaf Stüve, MD, PhD

Bernhard Hemmer, MD

Correspondence to

Dr. Stüve:

olaf.stuve@utsouthwestern.edu

Neurol Neuroimmunol

Neuroinflamm

2014;1:e52; doi: 10.1212/

NXI.0000000000000052
Many of the immune therapies that are currently approved or in development for patients with multiple sclerosis (MS) are potentially immunogenic recombinant proteins. ${ }^{1}$ Some of these proteins have amino acid substitutions, while others may differ from their endogenous counterparts by posttranslational modifications. Recombinant antibodies, including natalizumab, also induce immune responses that render them inactive and that cause some recipients to display a variety of symptoms that are discussed below. Even with the development of technologies that allow the development of fully humanized monoclonal antibodies, their immunogenicity could not be fully abolished.

With regard to immune responses to natalizumab, 2 curious phenomena can be discerned: (1) their incidence has substantially increased as the agent made its way through clinical development, and (2) the phenotype of hypersensitivity sensations is ill-defined.

The publication of an initial small placebocontrolled trial with natalizumab does not mention hypersensitivity reaction to natalizumab at all. ${ }^{2}$ Subsequently, several immune-related adverse events were reported in a phase 2 clinical trial. ${ }^{3}$ One out of 68 patients in the $3 \mathrm{mg} / \mathrm{kg}$ body weight natalizumab treatment group experienced an anaphylactoid reaction with urticaria and bronchospasm. In addition, there were 3 reports of serum sickness, one in each natalizumab treatment group and one in the placebo group. It is interesting that all 3 of these events occurred at a single study site. In one of the phase 3 trials (AFFIRM ${ }^{4}$ ), $4 \%$ of natalizumab recipients had hypersensitivity reactions, including urticaria or generalized urticaria, allergic dermatitis, hypersensitivity, and 5 patients with anaphylactic or anaphylactoid reactions. The majority of reactions occurred on the second infusion. In the second phase 3 trial (SENTINEL ${ }^{5}$ ), $1.9 \%$ of patients assigned a combination therapy of 2 potentially recombinant immunogenic proteins, natalizumab and interferon $\beta$-1a (Avonex), had a hypersensitivity reaction, 8 of which were isolated cases of urticaria. Despite the mostly benign outcomes from these hypersensitivity reactions, neurologists would like to be able to predict which of their patients is at risk. If a diagnostic test existed, a decision might be made to monitor these individuals more closely or to initiate another pharmacotherapy.

In the current issue of Neurology ${ }^{\circledR}$ Neuroimmunology \& Neuroinflammation, de la Hera et al. ${ }^{6}$ investigated potential associations between human leukocyte antigen (HLA) class I and class II alleles and the development of anaphylactic or anaphylactoid reactions in patients with MS treated with natalizumab. A total of 54 patients with natalizumab-related anaphylactic or anaphylactoid reactions and 65 patients without allergic reactions recruited at 3 sites were included in the study. Information on anti-natalizumab idiopathic neutralizing antibodies (Nabs) that are frequently associated with infusion reactions was available in only half of the 54 patients with MS who developed infusion-related anaphylactic or anaphylactoid reactions, and $81.5 \%$ of patients were seropositive. There is no information on the antibody status of the other 65 patients. Overall, this lack of data makes the results of this study difficult to interpret.

A definition for anaphylactoid reactions is not provided, but anaphylaxis is described as a severe, potentially fatal systemic allergic reaction that occurs suddenly after contact with an allergy-causing substance. $^{7}$ The authors show that HLA-DRBI*13 and $H L A-D R B 1^{*} 14$ alleles are significantly increased in patients who developed anaphylactic or anaphylactoid reactions. In contrast, the $H L A-D R B 1^{*} 15$ allele is significantly more represented in patients who did not develop these reactions. The sample size was too small to address the question of whether those alleles 
are also associated with the development of Nabs to natalizumab. This is a relevant issue, as an immunoglobulin switch would require natalizumab-specific $\mathrm{CD}^{+}$T-helper cells. The authors also did not attempt to replicate their findings in an independent cohort as is usually requested for genetic studies.

Would HLA-DRB1 genotyping before natalizumab treatment help neurologists identify patients with MS at risk for developing serious systemic hypersensitivity reactions associated with natalizumab, as concluded by the authors? This conclusion almost certainly does not apply to all hypersensitivity reactions that have been described after natalizumab administration. HLA class I and II are major histocompatibility complex (MHC) molecules that mediate antigen presentation to $\mathrm{CD}^{+}$cytotoxic $\mathrm{T}$ cells and $\mathrm{CD}^{+}$ T-helper cells, respectively. MHC-restricted antigen presentation is not required for anaphylaxis to occur. During allergic reactions (type I hypersensitivity), immunoglobulin E binds directly to the immunogenic protein and activates $\mathrm{Fc}_{\mathrm{c}}$ receptors on mast cells and basophils, which then release histamine. Some foreign proteins can directly cause the degranulation of these cells. Anaphylactoid reaction, a reaction resembling generalized anaphylaxis but caused by a nonimmunologic mechanism, by definition is not MHCrestricted. ${ }^{8}$ Serum sickness, or immune complex hypersensitivity (type III), as reported in 3 patients in the phase 2 clinical trial with natalizumab, ${ }^{3}$ is an antibody reaction against nonhuman proteins in serum that occurs 4-10 days after exposure. MHCrestricted antigen presentation is not required.

In delayed type hypersensitivity (type IV), symptoms typically develop 48-72 hours after antigen exposure. This type of hypersensitivity is indeed mediated by $\mathrm{CD}^{+}{ }^{+}$T-helper cells and late $\mathrm{CD} 8^{+}$ cytotoxic $\mathrm{T}$ cells. Thus, type IV hypersensitivities do require $\mathrm{MHC}$-restricted antigen presentation. As immune-mediated reactions to natalizumab typically occur after repeat exposure, some of the reported hypersensitivity reactions are likely type IV.

There are 3 severe cutaneous adverse drug-induced hypersensitivity reactions that are associated with HLA alleles: (1) Stevens-Johnson syndrome/toxic epidermal necrolysis (SJS/TEN), (2) drug reaction with eosinophilia and systemic symptoms, and (3) drug-induced hypersensitivity syndrome. Of interest, these reactions have been almost exclusively described with small molecules, not with proteins. ${ }^{9}$ Some of these associations are biologically relevant, and HLA genotyping certainly may assist in guiding decision-making in some clinical situations. For instance, since 2007 the US Food and Drug Administration has recommended genotyping for $H L A-B^{*}$ 15:02 prior to initiating carbamazepine in patients with Asian ancestry in order to avoid SJS/TEN. ${ }^{10}$
Hypersensitivity reactions to natalizumab are rare and usually not life-threatening. Many of these reactions are related to Nabs to natalizumab, which can easily be detected by standardized assays. Even if the findings of the study are replicated in an independent cohort and further studies elucidate the immunologic background that leads to the generation of anti-natalizumab Nabs, it seems unlikely that predictive genetic testing will ever become routine clinical practice.

\section{STUDY FUNDING}

No targeted funding reported.

\section{DISCLOSURE}

O. Stüve is on the editorial board for JAMA Neurology, Therapeutic Advances in Neurological Disorders, Clinical and Experimental Immunology, and MS Journal and receives research support from Teva Pharmaceuticals, Opexa Therapeutics, and Merit Review Grant from the Department of Veterans Affairs. B. Hemmer is an advisory board member for trials conducted by Bayer, Biogen-Idec, Roche, Novartis, Merck-Serono, Chugai, GSK, and Genetech; has received travel funding and/or speaker honoraria from Bayer, Biogen-Idec, Roche, Novartis, and Merck-Serono; holds a patent for anti-KIR4.1 antibody testing in MS and genetic factors influencing the development of NABs; receives research support from Bayer, Biogen-Idec, Roche, Novartis, Merck-Serono, Matanomics, Chugai Pharmaceuticals, Protagen, Deutsche Forschungsgemeinschaft, Bundesministerium fur Bildung und Forschung, European Community, Competence Network for Multiple Sclerosis Synergy, Excellence Cluster, and German Research Foundation. Go to Neurology.org/nn for full disclosures.

\section{REFERENCES}

1. Hemmer B, Stuve O, Kieseier B, Schellekens H, Hartung HP. Immune response to immunotherapy: the role of neutralising antibodies to interferon beta in the treatment of multiple sclerosis. Lancet Neurol 2005;4: 403-412.

2. Tubridy N, Behan PO, Capildeo R, et al. The effect of anti-alpha4 integrin antibody on brain lesion activity in MS. The UK Antegren Study Group. Neurology 1999;53: 466-472.

3. Miller DH, Khan OA, Sheremata WA, et al. A controlled trial of natalizumab for relapsing multiple sclerosis. N Engl J Med 2003;348:15-23.

4. Polman CH, O'Connor PW, Havrdova E, et al. A randomized, placebo-controlled trial of natalizumab for relapsing multiple sclerosis. N Engl J Med 2006;354: 899-910.

5. Rudick RA, Stuart WH, Calabresi PA, et al. Natalizumab plus interferon beta-1a for relapsing multiple sclerosis. N Engl J Med 2006;354:911-923.

6. de la Hera B, Urcelay E, Brassat D, et al. Natalizumabrelated anaphylactoid reactions in MS patients are associated with HLA class II alleles. Neurol Neuroimmunol Neuroinflamm 2014;1:e47. doi: 10.1212/NXI. 0000000000000047.

7. Sampson HA, Munoz-Furlong A, Campbell RL, et al. Second symposium on the definition and management of anaphylaxis: summary report-Second National Institute of Allergy and Infectious Disease/Food Allergy and Anaphylaxis Network symposium. J Allergy Clin Immunol 2006;117:391-397. 
8. The Free Dictionary. Anaphylactoid definition. Available at: http://medical-dictionary.thefreedictionary.com/anaphylactoid. Accessed October 30, 2014.

9. Cheng $\mathrm{CY}, \mathrm{Su} \mathrm{SC}$, Chen $\mathrm{CH}$, Chen WL, Deng ST, Chung WH. HLA associations and clinical implications in T-cell mediated drug hypersensitivity reactions: an updated review. J Immunol Res 2014;2014:565320.
10. US Food and Drug Administration. Information for healthcare professionals: dangerous or even fatal skin reactions-carbamazepine (marketed as Carbatrol, Equetro, Tegretol, and generics). Available at: http:// www.fda.gov/Drugs/DrugSafety/PostmarketDrugSafety InformationforPatientsandProviders/ucm 124718.htm. Accessed October 30, 2014. 


\section{Neurology \\ Neuroimmunology \& Neuroinflammation}

The genetics of natalizumab hypersensitivity: One learns to itch where one can scratch

Olaf Stüve and Bernhard Hemmer

Neurol Neuroimmunol Neuroinflamm 2014;1;

DOI 10.1212/NXI.0000000000000052

This information is current as of December 11, 2014

Updated Information \&

Services

References

Subspecialty Collections

Permissions \& Licensing

Reprints including high resolution figures, can be found at:

http://nn.neurology.org/content/1/4/e52.full.html

This article cites 8 articles, 0 of which you can access for free at: http://nn.neurology.org/content/1/4/e52.full.html\#\#ref-list-1

This article, along with others on similar topics, appears in the following collection(s):

Multiple sclerosis

http://nn.neurology.org//cgi/collection/multiple_sclerosis

Information about reproducing this article in parts (figures,tables) or in its entirety can be found online at:

http://nn.neurology.org/misc/about.xhtml\#permissions

Information about ordering reprints can be found online: http://nn.neurology.org/misc/addir.xhtml\#reprintsus

Neurol Neuroimmunol Neuroinflamm is an official journal of the American Academy of Neurology.

Published since April 2014, it is an open-access, online-only, continuous publication journal. Copyright $\odot$ 2014 American Academy of Neurology. All rights reserved. Online ISSN: 2332-7812.

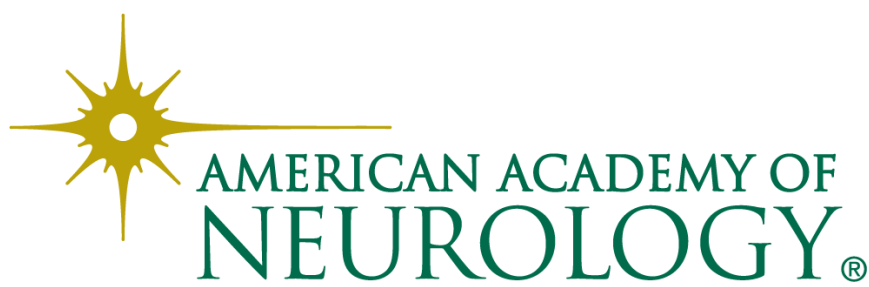

